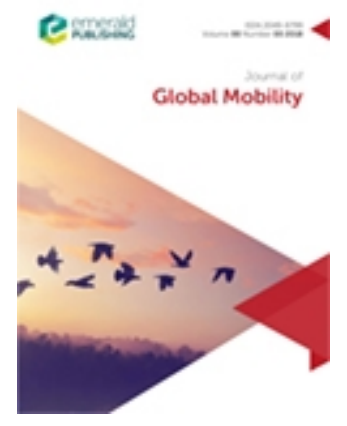

\title{
Host country employees' negative perceptions of successive expatriate leadership: the role of leadership transference and implicit leadership theories
}

\begin{tabular}{|r|l|}
\hline Journal: & Journal of Global Mobility \\
\hline Manuscript ID & JGM-04-2021-0044.R3 \\
\hline Manuscript Type: & Research Paper \\
\hline Keywords: & $\begin{array}{l}\text { successive expatriate assignments, Host Country Employees, perceptions } \\
\text { of successive assignments, subsidiary, expatriate leadership schema, } \\
\text { implicit leadership theories, intrinsic qualitative case study, leadership } \\
\text { transference }\end{array}$ \\
\hline Authors: & Sylwia Ciuk and Doris Schedlitzki \\
\hline
\end{tabular}

\section{SCHOLARONE ${ }^{\text {M }}$ \\ Manuscripts}




\section{Host country employees' negative perceptions of successive expatriate leadership: the role of leadership transference and implicit leadership theories}

\section{Introduction}

The importance of perceptions and attitudes of host country employees (HCEs) towards expatriates has long been recognised. The bulk of work has focused on how these perceptions and attitudes impact HCEs' willingness to offer support to expatriates (e.g. Varma et al., 2012; Varma, et al., 2016 a, b; Shen et al., 2018; Yamao et al, 2020) and, by extension, contribute to expatriate success (Kang and Shen, 2018; van Bakel, 2019). The literature has generated valuable insights into the factors that affect the attitudes of HCEs towards expatriates. A rich strand of work has considered expatriate characteristics, qualities, skills and behaviours, and the underlying mechanisms (e.g. Peltokorpi and Froese, 2014; Selmer and Lauring, 2013; Zhang and Harzing, 2016; Varma et al., 2020; Wang et al., 2014). Others, by contrast, have unpacked the role of the preferences, characteristics and identification of HCEs (e.g. Peltokorpi, 2020; Syed et al., 2014; Templer, 2010) as well as the impact of contextual factors, such as culture (Grodzicki and Varma, 2011) or organisational policies and practices (e.g. Aris, 2014; DeNisi et al., 2006; Shen et al., 2018).

Previous studies have, however, not studied these attitudes in the context of successive expatriate leadership assignments. This is despite compelling evidence from leadership scholarship of the influence of previous experiences on followers' implicit leadership theories (Lord and Maher, 1993) and the phenomenon of leadership transference (Ritter and Lord, 2007). These theories argue that past experiences with leaders, as stored in people's memories, are activated, often subconsciously, to evaluate and form expectations of oncoming leaders (Song et al., 2015). Most expatriate studies seem to make an implicit assumption that expatriate assignments can be investigated in relative isolation without a careful consideration of how 
HCEs' experiences with expatriates' predecessors affect their perceptions and, by extension, relationships with on-coming expatriates. We see this assumption as problematic, in particular because of the likelihood that HCEs work with a few successive expatriate leaders, often in the course of their employment with one organisation (Fee, 2020) and are thus likely to have developed mental representations of them.

Our study contributes to the expatriate-HCEs relations literature by illustrating how leadership transference research (Lord and Maher, 1993) and implicit leadership theories (e.g. Lord and Maher, 1993; Offermann and Coats, 2018) advance our understanding of HCEs' perceptions of successive expatriate leadership. We apply this theoretical framework to an intrinsic case study (Flyvbjerg, 2006; Stake, 1995) based on forty interviews with HCEs in a Polish subsidiary of an American MNE that capture their retrospective accounts of being managed by a string of expatiate leaders. We demonstrate how HCEs' memories of past experiences with expatriate leaders as well as their implicit leadership theories affected their negative perceptions of successive expatriate leadership. More specifically, we propose a new concept - expatriate leadership schema - to describe HCEs' cognitive structures, developed during past experiences with successive expatriate leaders in a specific cultural context, which specify what HCEs believe expatriate leadership to look like and what they expect from it.

We argue that it is particularly important to explore successive expatriate leadership from the perspective of HCEs for two main reasons. First, while expatriates are often peers and subordinates of HCEs, they also continue to occupy key leadership positions (Bebenroth and Froese, 2020; DeNisi et al., 2006), including general management roles. Despite localization trends, it is not uncommon for subsidiaries, especially newly established ones and those in emerging markets (Bruning et al., 2011), to be managed by successive expatriate leaders. While expatriate placements offer opportunities for the hosting organisation, they also carry a hidden cost for the local workforce, such as extra role demands, (Fee, 2020) and can cause significant 
disruption (Fee and Michailova, 2020). These disruptions can be more pronounced, longer lasting and affect a larger proportion of the workforce in the case of successive assignments in key leadership positions. The perspective of HCEs, while growing in representation (Kang and Shen, 2018; van Bakel, 2019), however, tends to receive less academic attention (Andresen, 2019; Peltokorpi, 2020; Zhang and Harzing, 2016). Secondly, exploring the perspective of HCEs who experience successive expatriate leadership as disruptive can help us better understand and address the causes of their negative perceptions. This is important not only because these perceptual and attitudinal aspects affect expatriate-HCEs interactions but also because we see HCEs as a crucial stakeholder in their own right (Fee, 2020; van Bakel, 2019). Building on retrospective accounts of HCEs, we therefore ask the following research question: How do HCEs' shared past experiences affect their perceptions of successive expatriate leadership?

Locating our work within the expatriate-HCEs relationships literature, we start by providing a brief overview of studies looking at the perceptions and attitudes of HCEs towards expatriates. We then outline our conceptual framework which draws on the notion of leadership transference and implicit leadership theories. After introducing our case study organisation and outlining our methods, we present the findings of our intrinsic case study. We end by discussing our findings against the backdrop of existing studies and consider theoretical and practical implications of our work.

\section{Previous studies on HCEs' perceptions and attitudes towards expatriate leaders}

The extant expatriate literature has provided valuable insights into the expatriate skills, attributes and behaviours, contextual factors and HCEs' perceptions and attitudes towards 
expatriates that affect expatriate-HCEs relationships (Kang and Shen, 2018). We provide a concise overview of key insights as a background to our study.

Research on expatriate-HCEs relationships at an individual and, to a lesser extent, on a dyadic level of analysis (van Bakel, 2019) tends to focus on the attributes, skills and behaviours of expatriates. These have been shown to enable them to better adapt to the local setting and to build quality relationships with HCEs (e.g. Caligiuri, 2000; Mahajan and DeSilva, 2012; Toh and DeNisi, 2005). Existing studies have particularly pointed to the importance of attributes such as cultural sensitivity (Mahajan, 2011), openness and sociability (Caligiuri, 2000), cultural intelligence (Stoermer et al, 2020), perceived professionalism (Sokro and Pillay, 2020), as well as skills and skill clusters (Wang et al., 2014), such as language and communication (e.g. Peltokorpi and Pudelko, 2021). They have also highlighted attributes, such as expatriate ethnocentrism (Sonesh and DeNisi, 2016), which undermine these relationships. The position of expatriates also plays a role as HCEs were found to be more willing to provide role-related support to peers and subordinates than to supervisors (Varma et al., 2011b). Others have examined the role of behaviours exhibited by expatriates in affecting the attitudes of HCEs, such as their socialisation tactics (Selmer, 2001) or reluctance to invest in relationships with their local colleagues (Przytuła et al., 2015), which might be exacerbated by overconfidence in their familiarity with the local culture (Cheung, 2008).

A second line of investigation focuses on the preferences, perceptions and, less commonly, characteristics and attitudes of HCEs towards a specific group of expatriates. Studies have, for example, shown that openness to experience (Arman and Aycan, 2013), HCEs' ethnocentrism (Varma et al., 2011a; Varma et al., 2012), and in-group collectivism (Stoermer et al., 2020; Varma et al., 2016b) are significantly correlated, the former positively and the two latter negatively, with positive outcomes. These positive outcomes include among others, HCEs' willingness to support expatriates or expatriate embeddedness in the host 
organisation. With regards to the preferences and perceptions of HCEs, Templer's (2010) study has found that job knowledge, relational leadership skills, cultural openness and adaptability were related to expatriate success. Relational leadership skills were seen as the most important attribute. This line of investigation has also generated insights into the concerns expressed by HCEs, for example with regards to the expatriates' ability to adjust to the local culture and thus to successfully manage foreign subsidiaries (Syed et al., 2014). Different nationality can become an obstacle if expatriates are unable to successfully operate in the local business context or when the nationality difference is salient in a given context (Sonesh and DeNisi, 2016).

The third strand of work relevant for our study explores the influence of contextual factors on expatriate-HCEs relationships (Kang and Shen, 2018; Shen et al., 2018). Banai and Reisel (1999), for example, describe the role of the heterogeneity of the setting in impacting HCEs' willingness to trust their superiors. In their study, participants were more likely to trust same-nationality superiors if they worked in a nationally homogenous setting. If the setting was nationally heterogeneous, the supervisor's nationality did not appear to play a role in trust formation. Other studies have demonstrated how HRM practices and policies undermine the expatriate-HCEs relationships when they are seen as favouring expatriates with regards to remuneration, benefits and career opportunities (Ariss, 2014; DeNisi et al., 2006). HRM practices, however, can also facilitate expatriate-HCEs relationships. For example, highcommitment and socially responsible HRM practices have been found to increase HCEs' willingness to help expatriates (Shen et al., 2018). A common organizational identity can also perform a similar role (Peltokorpi, 2020). Finally, a few studies have explored the influence of culture on expatriate-HCEs relationships (e.g. Selmer 1996, 1997; Grodzicki and Varma, 2011; Varma et al., 2012), yet with mixed results. This body of work often highlights the importance 
of cultural differences between expatriate and HCEs and the need for adjustment (e.g. Grodzicki and Varma, 2011; Varma et al., 2009; Varma et al., 2012).

While these previous studies have advanced our understanding of factors affecting HCEs' perceptions and attitudes towards expatriates, they have not considered how these factors play out in the context of successive expatriate assignments. We therefore turn to research into leadership transference and implicit leadership theories to create our analytical framework.

\section{Leadership transference and implicit leadership theories}

To advance our understanding of how HCEs' shared past experiences affect their perceptions of successive expatriate leadership, we turn to two socio-cognitively orientated strands of work within leadership studies: transference studies and implicit leadership theories.

Ritter and Lord (2007: 1683) define transference in the context of leadership as "the use of a mental structure developed in a previous relationship to automatically guide cognitive and emotional processes in a new relationship". These processes are moderated by leader characteristics that are salient for the followers in a given context. Transferential actions prompt followers to subconsciously react towards present leaders reminiscent of a past leader as they did towards the past leader. This enhances our analytical framework by suggesting that past experiences with specific leaders influence the interactions and relationships that followers can build with a new leader. In other words, the interactions and relationship with the new leader become intertwined from the outset with those they had with the past leader. As Kets de Vries and Balazs, (2011: 387) observed, no relationship is ever new as "all relationships are colored by previous relationships". 
Transference effects apply to positive and negative treatment expectations which, in turn, have significant implications for the formation of new leader-follower relations (Ritter and Lord, 2007). They can, for example, lead to a self-fulfilling prophecy, whereby followers expecting unjust treatment react accordingly thereby undermining their work performance and relationships with new leaders. Transference studies differ markedly from existing leadership succession frameworks that usually explore single succession events (e.g. Ballinger and Schoorman, 2007; Farah et al., 2020). Indeed, the concept of transference enables us to look beyond a single succession episode and is therefore particularly relevant in the context of successive expatriate leadership. Interestingly, despite these illuminating insights into transference processes, there are to date no studies that look at the instance of transference in successive expatriate assignments.

Building on this notion of transferential actions, we are interested in understanding further the wider cognitive processes that lead to particular views on leadership based on past experiences and how these may influence present and future attitudes towards leaders. This is where we turn our attention to implicit leadership theories. Implicit leadership theories capture not only the influence of past experiences with individuals (as is the case for transference studies) but also recognise the importance of cultural contexts. Implicit leadership theories explore how individuals develop cognitive schemata or prototypes that specify the traits and abilities that characterise leaders, thus shaping their perception of and attitudes towards others (Braun et al., 2017; Epitropaki et al., 2013; Junker and van Dick, 2014; Offermann and Coats, 2018; Offermann et al., 1994). Informed by cognitive categorisation theory (Rosch, 1978), an individual's implicit leadership theory is defined as a cognitive structure or schema of leadership that has been developed over time and through prior experiences with leaders and followers, socialisation processes situated within cultural contexts and learned behaviours (Lord and Maher, 1993; Stock and Oezbeck-Potthoff, 2014). This cognitive schema is activated 
when individuals interact with someone who resembles that category (Epitropaki et al., 2013). These implicit theories are people's individual constructions and represent their subjective perceptions of reality. They shape the way individuals interpret, explain and predict both effective and ineffective leadership attributes, actions and behaviours of themselves and others in everyday life (Offermann and Coats, 2018; Schyns and Schilling, 2011).

As Offerman and Coats (2018: 514) observe, implicit leadership theories "can be both stable and mutable, with new schema being created when matches to existing schema cannot be found while matched schema continue to persist". These changes in schema can also be attributed to changes in context which place new expectations on leaders. Similar to transference studies, Schyns and Schilling (2011) highlight the dangers of self-fulfilling prophecies, whereby individuals holding a more ineffective image of leaders may perceive and evaluate their actual leaders more negatively. This recognises that past individual experiences and shared, cultural context will influence what individuals recognise as leadership and who they perceive to be effective or ineffective leaders (Riggs and Porter, 2017). Of notable importance for our analytical framework in this paper is research evidence on the impact of these cognitive schemata on followers' perceptions of specific leaders (Junker and van Dick, 2014) and the influence that the mutual assessment of fit into leader/follower categories has on the leader-follower relationship (Riggs and Porter, 2017).

In summary, we address the paucity of research into successive expatriate leadership assignments by using an analytical framework based on insights from transference processes and implicit leadership theory. We do so to inform our understanding of the role of HCEs' shared past experiences with individuals and in specific cultural contexts in affecting their perceptions of successive expatriate leadership. Before we analyse the findings from our study, we introduce the case study organisation and outline the methodology of our research. 


\section{Methods}

\section{The Case organisation}

Our data come from an intrinsic case study (Stake, 2005) based on forty interviews with HCEs of Pharma (a pseudonym). Pharma is a Polish subsidiary of an American pharmaceutical corporation, here called PharmaGlobal. At the time of data collection, Pharma, a sales and marketing subsidiary, employed over two hundred employees and had recently appointed its first local General Manager (GM). PharmaGlobal employs over 90,000 staff worldwide and operates in more than 100 countries. It generates revenues of nearly 40 billion dollars, produces both pharmaceuticals and medical devices and makes substantial investments in research and development of innovative patented products. According to FORTUNE, it has been listed among America's Most Admired Companies' for over twenty years.

At the time of data collection, the Polish subsidiary had been on the Polish market for over ten years and had been led by four expatriate leaders who each stayed in Poland for just over two years and a newly appointed Polish GM. The expatriate leaders were third country nationals from PharmaGlobal. The first expatriate leader originally came from France. He was followed by an assignee from Mexico, who in turn was succeeded by a Canadian GM. The fourth expatriate leader came originally from New Zealand. He was replaced by a local Polish executive, a former medical doctor with an MBA degree, who joined Pharma from one of its competitors. The expatriate executives moved to Poland from other assignments, rather than the HQs, and subsequently took on further international posts. Only one of them, the fourth, New Zealand executive, had previous experience in general management roles, albeit lasting only a year. The expatriate leaders held bachelor's degrees in different fields such as engineering, surgical technology and marketing. The Polish workforce was highly ethnically homogenous - composed of Polish nationals, bar one member of staff from another Eastern 
European country who spoke fluent Polish. Most employees had master's degrees, with a number of staff in more senior roles with master's degrees in medicine.

In order to better understand the perceptions of successive expatriate leadership in our case study, a few additional external factors need to be considered. The first expatriate leader joined the Polish unit after a few months of its establishment as a greenfield operation. There was no formal GM in place up to this appointment. It was a time of considerable growth and very favourable market conditions. The market growth continued during the incumbency of his successor, the Mexican GM. However, at that time PharmaGlobal took over another pharmaceutical company, the integration of which posed a significant challenge in Poland. The challenges, inherent in take-overs, were exacerbated by the perceived very different working styles of staff, especially sales representatives, in the two companies. Some of the longest serving staff at Pharma came from the taken over company.

The vacancy created by the departure of the Mexican GM was filled by a Canadian executive whose time at Pharma coincided with more demanding market conditions. These were associated with challenges with keeping the company's drugs on the government reimbursement list, government pressures on price reductions and the resulting deteriorating financial performance of the subsidiary. Financial pressures continued during the incumbency of the fourth expatriate GM - a New Zealander - when the subsidiary consistently failed to meet the HQs' sales targets. His leadership coincided with increased media scrutiny of pharmaceutical companies associated with a number of high-profile scandals affecting the company's competitors and a political climate marked by a strong anti-corruption rhetoric by the government. During the incumbency of the New Zealand expatriate, Pharma's market share took a tumble as did its financial performance, while voluntary and involuntary turnover totalled over forty percent annually. Under the leadership of his Polish successor the negative 
performance trend was reversed, with the subsidiary meeting the HQs' sales targets and managing to gradually rebuild its weakened market position.

\section{Data collection methods}

Access to Pharma was granted under the condition of anonymity and in return for a research report. The organisation was known to the first author who carried out a culture study there three years prior to the commencement of the current project, just before the departure of the third expatriate GM. Our insights come from forty semi-structured interviews carried out in Polish by the first author, twenty-one of which were conducted with HCEs who had been managed by at least three expatriate leaders, whereas ten had been managed by one expatriate. To enhance the richness of our study, we used a dynamic adaptive approach to sampling (Plakoyiannaki and Budhwar, 2021) which combined purposeful and maximum variation sampling to represent different departments, length of service, seniority and exposure to expatriates (see Table 1). In line with our concern with the under-researched (Andresen, 2019; Peltokorpi, 2020; Zhang and Harzing, 2016) but crucial role of the HCEs' perspective on successive expatriate leadership, we focussed exclusively on HCEs' perceptions. We see the perceptions of HCEs as fundamental in understanding expatriate leadership. Our focus on the followers' perspective mirrors a growing body of work within leadership studies. As Lord and Emrich (2000: 551) observed, "If leadership resides, at least in part, in the minds of followers, then it is imperative to discover what followers are thinking."

[Insert Table 1 about here]

Interviews lasted on average an hour and were transcribed in full. The interview guide combined a retrospective and contemporary focus. It included questions about participants' history in the organisation, their experiences with the expatriate GMs and the subsidiary's situation during these times. It also focussed on the local GM and their assessment of the 
current situation of the subsidiary, the introduced changes as well as their hopes for the future of the subsidiary. In line with our social constructivist approach (Berger and Luckmann, 1966), we view HCEs' retrospective accounts as their constructions of past events which have a bearing on their attitudes and actions, indicating perceptions and sense making efforts rather than factual reports. Exploring the role of past experiences as reflected in people's cognitive structures is a long-standing tradition in socio-cognitive studies, including the two strands of work which form our theoretical framework, namely leadership transference (Ritter and Lord, 2007) and implicit leadership theories (e.g. Schyns and Schilling, 2011).

\section{Data analysis}

Data analysis followed abductive reasoning (Mantere and Ketokivi, 2013; Sætre and Van de Ven, 2021). Analysis commenced with a detailed reading of the untranslated transcripts and open coding (Strauss and Corbin, 1998) by the first author. This first round of analysis resulted in a comprehensive set, counting approximately two hundred, open codes, many of which referred to the current situation of the subsidiary. To tease out insights on expatriate leadership, analysis shifted to focused coding (Thornberg and Charmaz, 2014). This procedure entailed zooming in on interview excerpts that pertained directly to HCEs' views on particular expatriates, expatriate leadership as a general category, successive expatriate assignments, the local GM and comparisons between expatriate and local leaders and leadership. In keeping with the importance of contextualisation in case study research (e.g. Piekkari and Welch 2018), we remained attuned to codes pertaining to organisational context, past and present, and how they were linked to evaluations and HCEs' perceptions.

The next stage of analysis entailed reviewing and grouping codes in search for themes and patterns (Braun and Clarke, 2012). The first author, in discussions with the second author, compared sections devoted to each of the expatriate GMs which contained quotes focused on 
their qualities, behaviours, interactions, HCEs' evaluations and their attitudes to individual leaders. These codes were grouped under a theme of experiences with previous expatriate leaders. She did the same for sections focused on the first Polish GM. We looked for patterns underlying positive and negative evaluations. Subsequently, we focused on excerpts discussing expatriate leadership as a general category. We noticed that perceptions of expatriate leadership were not only built around generalised views about expatriate leaders (which contained codes on expatriate qualities, behaviours, HCEs' expectations of treatment from expatriate leaders and attributed motives) but also included perceptions of an assignment pattern and its consequences. Because of the general nature of these descriptions, we labelled this core theme as expatriate leadership schema.

The current expatriate literature could not explain our findings and so, following abductive reasoning (Mantere and Ketokivi, 2013; Sætre and Van de Ven, 2021), we turned to the literature which has discussed the role of past influences on perceptions of and attitudes to new leaders. Two strands of work generated most relevant insights, namely leadership transference studies (Ritter and Lord, 2007; Song et al., 2015) and implicit leadership theories (e.g. Braun et al., 2017; Epitropaki et al., 2013; Junker and van Dick, 2014; Lord and Maher, 1993; Offermann and Coats, 2018; Offermann et al., 1994). More specifically, the concepts of transference (Ritter and Lord, 2007) and implicit leadership theory (e.g. Lord and Maher, 1993; Stock and Oezbeck-Potthoff, 2014) served as a useful analytical framework for our emerging themes. It also prompted us to return again to our data to examine whether there were other leadership schemata present in the retrospective and contemporary accounts of HCEs which could explain the value judgements made in relation to expatriate leaders. An additional round of analysis revealed not only the presence of HCEs' implicit leadership theories but also how they served as a platform for both, the retrospective evaluation of past expatriate leaders and 
the shaping of expectations towards future leaders. In what follows, we present the outcome of our analysis.

\section{Findings}

In this section we discuss how HCEs' retrospective and contemporary accounts of leadership reveal the influence of shared past experiences on their perceptions of successive expatriate leadership and the emergence of expatriate leadership schema. We explain the content of the schema and how it was influenced by past experiences with expatriate leaders and HCEs' implicit leadership theories. We start by outlining retrospective accounts of HCEs' experiences with past leaders and their implicit leadership theories before discussing schema pertaining to expatriate leadership.

\section{HCEs' shared experiences with the subsidiary's successive expatriate leaders}

There were considerable differences in how individual past expatriate leaders were perceived, with the first (French) and fourth (New Zealand) expatriates evoking intensively negative emotions, whereas the second (Mexican) and third (Canadian) expatriates being viewed in a more positive light. In fact, the Mexican GM was at times referred to as "the best GM [the subsidiary] has had" (\# 9 Darek). Despite the differences in assessment of each of the expatriate leaders, HCE's accounts highlight very similar themes which were used to praise or highlight shortcomings of the given expatriate leader. The accounts focused predominantly on the relational dimension by describing and evaluating expatriate leaders' behaviours when interacting with staff. The negatively perceived leaders were commonly presented as impulsive, coarse, unapproachable and controlling. They were often described as behaving in 
a dismissive manner towards HCEs. This is well captured in the quote below describing the first, French expatriate leader:

He was a hot-headed individual who could fire somebody for coming to a meeting in jeans. ... You could not be sure whether you would come back from a meeting with him. If you were 5 minutes late, the door was already closed. .... He was very sales oriented. I remember that he presented a slide which showed that we would do 30 sales visits a day. He had such strange ideas. He treated us as if we came from a seriously underdeveloped country; as if we resembled a strange race to him. Everybody was afraid of him. ... He had a very instrumental approach to people. I remember that every day a different team would have breakfast with him. He would quiz everybody about their performance. 'How much did you sell?' Why so little?!' Nobody could eat anything. He pretended that he praised people, but he scolded them. (\# 5 Kacper)

HCEs, as the above example illustrates, recalled the French expatriate leader as an excessively punitive and controlling GM who induced fear in staff. HCEs drew attention to unpredictable behaviour, as captured for example in the 'jeans' incident which was mentioned to us by four longest serving HCEs. The quote and other accounts painted a picture of a leader who treated staff with suspicion and superiority. Simultaneously, HCEs questioned the expatriate leader's business acumen in the local context, for example by citing a proposed three-fold increase in the sales visits KPI. Participants often admitted to harbouring negative feelings towards this leader, which was presented as a result of poor treatment and the expatriate's dislike for Poles and Poland. While the quote below refers to this first expatriate leader, similar concerns were also voiced regarding the most recent expatriate:

This was a boss that was widely disliked because he did not like Poles. He often highlighted how much he did not like Poland. ... He would call people morons. ... He 
did not end up well. He went to Belgium and was dismissed. ... Such people should not be in leadership roles. (\# 1 Anna)

The quote suggests that the negative affect on part of the expatriate leader was not discerned from subtle behavioural cues but was repeatedly and openly confirmed by the expatriate leader himself.

Similar perceptions were expressed in relation to the fourth, New Zealand, expatriate manager who was also depicted as erratic and curt. The accounts of his tenure bring to the fore another important relational dimension, namely trust. HCEs discussed how, in their experiences, the attitude of the expatriate GM towards them changed over time. Some admitted that he was initially perceived as "sensible and down-to earth" (\# 11 Jarek). At the start of his tenure, he worked closely with an influential local sales director - Norman (a pseudonym) who "invested a lot in this relationship and spent the first few months in [the GM's] office. One could tell that they got on very well and were speaking the same language" (\# 34 Patrycja). A discovery of an irregularity in a financial audit, however, triggered a thorough review and expansion of compliance procedures, a freeze of all marketing spending and eventually led to Norman's dismissal. HCEs reported struggling to adjust to what they perceived was unprecedented, distrust motivated, micromanagement:

He did not need product managers, or anybody else .... Product managers would present their forecasts to him, and he would challenge them so that they ended up writing down his numbers ... the following month he would ask them where these numbers came from. ... He interfered in everything. He was very hard working and demanded that others worked that hard.... My colleague sat for weeks in the office until 10 or midnight’. (\# 21 Małgorzata) 
The above-mentioned unwillingness to listen to staff, in particular subject experts, was interpreted as a sign of distrust and disrespect. It was blamed for unprecedented staff turnover and a loss of initiative among staff. Our data suggest that HCEs initially tried to challenge what they saw as problematic, if not harmful, business decisions. However, after repeated failed efforts, they withdrew their support:

Initially, when he introduced some paranoid rules, everybody tried to explain why they were not appropriate. We would then hear: 'Do it, because I say so' or 'If you cannot cope this this, I can send you on a training course.' Our initiative started to die out. We stopped fighting and started taking this sick reality for granted. (\# 12 Paula)

In contrast to the two unpopular expatriate leaders discussed so far, HCEs also recounted positive experiences. Interactions with the second expatriate leader, originally from Mexico, are particularly noteworthy. The qualities and behaviours that were highlighted in his descriptions closely corresponded to the critique of the other expatriate GMs. While he was also characterised as hot-headed, HCEs praised his ability to foster closer relationships with staff, his agreeableness, enthusiasm and openness. They described him as a reasonable, capable and professional manager, with impressive analytical skills, whom staff could openly talk to. His business acumen was often contrasted with other expatriate GMs:

He listened to all sides. During his incumbency first problems started to appear on the pharmaceutical market and he was the first one who had to deal with this. We all thought that he was doing a good job. ... He respected and valued his employees. He was not a boss that is sat in his room. He knew everybody's name, where they work and what they do.... [His successor, the Canadian GM] had absolutely no idea what we were talking about; he did not understand our slides with numbers; he did not understand graphs .... He avoided such topics. ... He was a quiet boss, an unnoticeable 


\begin{abstract}
one. Probably because he did not know much, he avoided confrontation. ... During his incumbency we stopped talking about the business, about sales and the numbers. Projects about the company atmosphere started to matter and this is when the atmosphere began to deteriorate. We missed the progress that we enjoyed under the Mexican GM (\# 2 Monika).
\end{abstract}

The quote above is a good example of how expatriate GMs were evaluated against each other. It contains implicit references to other GMs (the first French and the most recent New Zealand expatriate) who were seen as not valuing local staff and unable or unwilling to form closer relationships with them. It also explicitly critiques the successor, the Canadian GM, who, while approachable and friendly, was seen as lacking the required business acumen and unable to make difficult decisions.

He did not know how to ensure that people delivered. We talked about one thing for three, four months. He did not check the progress ... we had massive price cuts and we stopped hitting our targets. He had no clue what was happening here and that we had agreed to these price cuts. (\# 12 Paula)

Both the Canadian and the Mexican GMs were praised for displaying trust to staff, especially their direct reports, including the earlier mentioned influential Polish sales director as a pivotal figure in HCE accounts. Displays of trust were linked to the fact that operational decisions, such as targets for sales visits for sales reps, were left for the local staff to make, relying on their understanding of the local market and other HCEs. Some, especially sales, staff described the influential Polish sales director as running the company:

When [the Canadian expatriate] was our GM, Norman was our sales director, and he was our 'real' GM. He was a buffer between the expatriate GM and us. ... He was the 
one who communicated with us. ... This was for the better for us and for the business. (\# 22 Ewa)

It is important to note that in their evaluations of expatriate GMs, HCEs often acknowledged the influence of the industry and organisational contexts - both as influences on the expatriate GMs' performance and their own sense-making of these past experiences. The early years of the operation were described as a great period for pharmaceutical companies, as they were launching previously unavailable drugs on the market so "the business was taking care of itself" (\# 11 Jarek). More challenging market conditions, such as Government triggered price cuts or changes on the list of reimbursed drugs, significantly affected sales results. These were acknowledged as contributing to increased pressure on later GMs - the Canadian and the New Zealand GMs - and facilitating the work of the first two. For example, the Mexican GM was described as being in a very fortunate position as "the market was booming so sales were rocketing” (\#4 Tomasz). However, he was also the one who had to oversee the integration of Pharma with another key market player taken over by Pharma Global. While staff from the taken over company, with very few exceptions, recalled this time as very traumatic, the Mexican GM's leadership of the integration phase was widely praised for its focus on fairness.

The Polish Pharmaceutical market was seen by participants as unique and demanding tailored strategies. This perceived specificity of the market as well as the particular position of the subsidiary, such as the length of its patents and availability (or lack) of new products were used to form evaluations of and expectations towards the expatriates and the first Polish GM. For example, the perceived increased vulnerability of the subsidiary strengthened expectations for providing inspirational motivation:

[The Polish GM] is showing us that there is a light at the end of the tunnel, that we are heading somewhere. ... we all worry that we have few products... All of our 
products are old, they will have generic equivalents soon. Everything depends on the boss's ability to show us that we can live with this and in fact grow. (\# 2 Monika)

The specificity of the market and the organisational context also informed HCEs' implicit leadership theories and expatriate leadership schema, as we will explain in the next section.

\section{HCEs' implicit leadership theories}

HCEs' accounts revealed the presence of implicit leadership theories which can be seen to shape their expectations and evaluations of the expatriates and the local GM. The most common theories identified in the data were those associated with given past leaders recalled by participants. We also identified general normative views on leadership without associations with specific leaders. The most referred to attributes of effective leadership were heavily influenced by the aforementioned influential Polish sales director - Norman. Many of the longer serving HCEs positioned this local executive as epitomising effective leadership despite admissions that he was also exceptionally demanding and, in many respects, uncompromising. The qualities, behaviours and ways of interacting with staff demonstrated by the first Polish GM were also often used to convey beliefs about effective GM level leadership. These implicit leadership theories typically highlighted decisiveness, business acumen and clarity of goals as well as openness to divergent views.

Norman was a strong boss. At that time staff expected somebody directive and knowledgeable. Norman liked being challenged by staff. His decisions were clear-cut. The [last, New Zealand] expatriate GM's decisions were directive, but staff did not agree with them. They disagreed with them but didn't tell him. Some rebelled and left. (\# 31 Patrycja) 
The implicit leadership theories suggested a preference for a more directive leadership style, although the directiveness was expected not to undermine staff's ability to influence decisionmaking:

I have had four other bosses after Norman, but nobody has lived up to him when it comes to the clarity of his communication or the precision of set goals... Everybody knew what they were supposed to do. Other bosses could not cope with this. ... He held everything together. Maybe did not give staff that much autonomy, especially when it comes to the sales team but ... everyone knew that he was on top of things. ... I very fondly remember his leadership style. (\# 13 Tatiana)

The first Polish GM was praised for his calmness, business and goal orientation, as well as a respectful approach to staff and their expertise which he did not challenge in daily encounters. This favourable account simultaneously implicitly critiqued unpopular traits, behaviours and approaches of selected expatriate GMs. The expectations of effective leadership could be interpreted as a response to negative experiences with expatriates who were perceived to lack these attributes. This transference of previous experiences can be seen to colour views and expectations of future GMs. Indeed, it has led to the shared expectation that a GM would have answers to strategic and operational problems and provide staff with reassurance that they were heading in the right direction:

[The Polish GM] is a total opposite to the last expatriate GM. He is calm, to the point, but he is also not afraid to insist on execution. He knows how to set priorities, what is important .... He acts as an image of a GM that I have - he has his right-hand man who communicates with us. ... People look up to them. He does not unnecessarily interfere in things. ... Once I sat next to him and I told him: 'We have a problem, we are not meeting our sates targets. People are demotivated...' And he tells me' Listen, 
this is not a problem. You have to do this and this'. He immediately knew what had to be done.' (\#8 Irek)

The quote above, corroborated by other interview data, suggests that a GM was expected to strike a delicate balance between providing a clear strategic oversight and solutions to business problems and simultaneously cultivating shared leadership with their direct reports and allowing others to exercise their judgement within their scope of duties.

\section{Expatriate leadership schema}

Our data shows clear links between HCEs' accounts of their past experiences and their implicit leadership theories with their general perceptions of expatriate leadership. We refer to these perceptions as expatriate leadership schema. Reflecting on their experiences, HCEs not only considered individual expatriates and evaluated them against each other, the Polish GM and their general expectations of a GM, but they also discussed what they saw as a pattern associated with the process of successive expatriate leadership. The expatriate leadership schema contained (a) generalised views about expatriates as leaders which we refer to as HCEs' expatriate leader theories, (b) descriptions of a characteristic pattern that expatriate leadership assignments were seen to adopt and (c) beliefs about the consequences of successive expatriate leadership. Expatriate leadership schema therefore is a broader category capturing three core elements of HCEs' perceptions of the successive expatriate leadership process. We will now discuss each of these elements.

a) HCEs' expatriate leader theories

Despite some notable positive past experiences with expatriate leaders, especially the Mexican GM, HCEs emphasized perceived shared negative characteristics of expatriate leaders. These were poor understanding of the local market context, a tendency to favour solutions from other 
contexts, mistrust and disrespect towards HCEs, rigidity in decision-making and self-serving, career-driven motives.

First of all, the expatriate GMs were seen as struggling to understand the specificity of the Polish pharmaceutical market, which, as we discussed earlier, was presented as very different from Western and other Eastern European markets:

Foreign bosses, as we've seen so far, are not able to grasp the specificity of our market. ... A Pole has a better chance because they know how a Pole will behave, how our healthcare system - which is an anomaly on a global scale- works. ... A person from outside will not get this .... [In Poland] he elderly won't let [the sales rep] jump the queue [in a GP practice]. They had enough of queuing in the 80s. .... A Polish boss will understand this. (\#19 Włodek)

The perceived uniqueness of the Polish pharmaceutical market was associated with the country's history, the political context and the customs and mentality of both patients and doctors. These factors were seen as impacting on how sales representatives could operate, the performance targets which were deemed attainable and effective marketing strategies. The commonly held view was that expatriate GMs underestimated both the uniqueness of the local market and its impact on business operations. They were also seen as struggling to effectively respond to its volatility. Some staff extended this concern to perceived expatriate struggles to understand the internal operations of the subsidiary, which was to a large extent linked to their inability to communicate in the local language and effectively deal with internal politics. As the only foreign born, albeit highly fluent in Polish, member of staff observed:

None of the expats have it easy here. They do not understand the realities of our organisation. None of the foreigners knew what was going on in our company. Their 
major problem was that they did not understand Polish, and everybody here speaks Polish on a daily basis. (\# 16 Kamil)

Another perceived common behavioural characteristic of expatriate GMs was their tendency to favour solutions from other contexts - "a mistaken belief that activities that worked in one market can be replicated elsewhere and will work in Poland" (\# 36 Borys). We acknowledge that there may have been a preference by the parent organisation for a centralised strategy being applied to this foreign market and that expatriates might have been sent to enforce this rather than to adopt local solutions. Yet, this was certainly not a preference shared by HCEs, with many expatriate-generated solutions viewed as unrealistic, ineffective and sometimes counterproductive. A strongly held view among HCEs was that the subsidiary needed to adopt context sensitive strategies in order to be effective. These strategies did not have to be innovative, as tested solutions from other companies in the local market, were also seen as appropriate. In fact, as discussed earlier, GMs were expected to readily offer solutions to strategic and operational problems and to be open to devising such strategies with experienced local staff. This reveals HCEs' concerns and shared opposition to super-imposed strategies by expatriate GMs, in particular when these were deemed maladjusted to the local context. The resulting tension between $\mathrm{HCE}$ views on effective strategies and expatriate GMs' actions, informed by MNE global strategies, are likely to negatively impact leader-follower relations and leadership effectiveness (Riggs and Porter, 2017).

The second component of expatriate leadership theories referred to the relational dimension and described HCEs' expectations of treatment from expatriate GMs. HCEs presented expatriate leaders as tending to approach the local workforce with distrust and oftentimes also disrespect. They were seen to "have a problem with valuing Poles, with respecting the employees." (\#6 Szymon). This perceived disrespect and distrust were typically discussed with reference to the perceived rigidity of the expatriates' decision-making process. 
Expatriate leaders were critiqued for displaying a tendency to impose their views and disregarding HCEs' concerns and counter-arguments. This was seen as highly problematic considering the earlier described perceived uniqueness of the Polish pharmaceutical market and gaps in expatriates' expertise. These conclusions were based on personal direct interactions with expatriate executives as well as observations and stories developed over the course of the successive GMs and shared among HCEs. As one assistant observed: "I never exchanged a word with [the most recent expatriate GM] but I was aware of people's experiences and knew what influence he had on others" (\# 23 Magdalena).

The final element of HCEs' theories of expatriate leaders referred to inferred expatriate motives. Managing the Polish unit was seen by the HCEs as a short step in the expatriates' international careers. Expatriate leaders were believed to be using the assignment in Poland to gain the relevant experience needed for their career advancement. As such, their objectives were understood to be different from the motivation of the HCEs:

[It is not good that] all the bosses are expatriates, that they come here for two or three years, and they all need to meet their own goals and that they don't care about the goals of our subsidiary. These are not the same goals. (\# 7 Danuta)

This interpretation of expatriate motives was particularly visible when participants contrasted them with those of their first local leader. Although the Polish GM admitted to being ambitious and therefore unlikely to stay long in the organisation, HCEs tended to project expectations of stability and a stronger subsidiary orientation.

b) Assignment pattern schema 
HCEs perceived expatriate assignments as following a predictable pattern and displaying similar characteristics. The underlying theme we found in the data depicts assignments as being of a transitional nature, requiring a relatively long time to proficiency and involving a period of increased volume and pace of change initiatives, which we refer to as change intensification, in their second half. We define time to proficiency after Waxin et al. (2019: 301) as the "time it takes expatriates, after starting the foreign assignment, to become proficient, i.e. to reach full performance in the official and informal demands of their job".

As most of the longer serving staff observed: "It was common knowledge that [the expatriate leaders] came for two years" (\# 2 Monika). The length of stay and the background of the assignees were used to infer that the assignments were of a transitional nature. As we mentioned earlier, the expatriate leaders were third country nationals who moved between subsidiaries and did not have any previous experience in the Polish market. Expatriate leadership appointments were thus often described as random and with an unclear logic, although such logic was plausibly more self-evident from the HQ's perspective:

We would always get somebody at random, [like in a carousel] more or less haphazardly (...) just as if it was all spinning somewhere. (\# 2 Monika)

The perceptions of a short-term and instrumental focus of expatriate leaders underpinned the expressed reservations towards successive expatriate leadership. The concerns about the shortterm transitional nature of expatriate executive assignments were further exacerbated by a perceived pattern in which they unfolded. Assignments were seen to entail a prolonged learning phase and an intensive change period in the second year of placement:

[the expatriate GMs] would learn for one year and then look for a better job for themselves during the second year. This is how we perceived it. There was always some rush, and a renewed focus, for example on effectiveness. (\# 4 Tomasz) 
Arguably, the perceived long time to proficiency could be largely explained by assignees' background and the perceived idiosyncratic nature of the Polish context. The perceived change intensification was linked to the observed tendency of expatriate leaders to seek to propose familiar solutions as a fix for local problems and the initiation of new projects. The changes introduced towards the end of expatriate assignments were seen as being self-serving. Only one expatriate leader - the Mexican GM - was described as breaking the familiar pattern, as "he did not keep saying for a year that he was new" (\# 2 Monika). This exception notwithstanding, longer serving staff formed expectations towards a distinctive behavioural pattern by successive expatriate leaders.

c) Perceived negative consequences of successive expatriate leadership

Staff who worked with two or more successive expatriate leaders tended to perceive expatriate assignments as not only having a negative impact on individuals and the relationships between staff and the expatriate leaders but also on the subsidiary. The negative consequences on individuals were mainly discussed in detail in relation to the most recent expatriate leader who was typically described as having "disrespected, hurt and demotivated a lot of people" (\# 16 Kamil) and "cost [individuals] their health" (\# 1 Anna). The negative consequences on the relationships and the subsidiary were associated with the assignment pattern and quick expatriate succession.

The perceived short-term nature of assignments was seen as posing challenges to the relationships between expatriate leaders and HCEs as it made it difficult for relationships to form. This was especially pronounced for staff who did not report directly to the expatriate leaders: 
If there is a constant change of bosses... what's the point of opening up to them? What's the point of talking to them today if we have a new boss the next day?' (\# 8 Irek)

Even very positive experiences with one of the past assignees were used to suggest that investment in these relationships was counterproductive. As Anna, one of the longest serving staff, recounted her personal story:

Once I had negotiated very good terms and conditions [with a different company] ... I go to [the Mexican general manager] and say: 'I am leaving'. Half an hour later he comes to my office, stands in the doorway and says: [Anna] don't go.' I was so stupid that I said: 'Alright.' I called the other company, and I rejected their offer. And soon afterwards [he] left us. (\#1 Anna)

The short assignment length was believed to be insufficient for the changes to be fully implemented before being replaced by new initiatives, which undermined continuity. The speed and frequency with which expatriate leaders introduced changes was seen as preventing a clearer vision. A compelling vision and reassurance were seen as particularly desirable considering the challenging conditions on the market and the company's aging product portfolio.

\section{Discussion}

In this paper we have proposed a shift in attention from a focus on the attributes, behaviours and skills of individual expatriates, or a particular group of expatriates, (e.g. Mahajan and DeSilva, 2012; Peltokorpi and Pudelko, 2021; Stoermer et al, 2020) to the underexplored, albeit empirically and theoretically significant, phenomenon of successive expatriate leadership assignments. We adopt the relatively under-represented perspective of HCEs (Andersen, 2019; 
Peltokorpi, 2020; Zhang and Harzing, 2016) for whom hosting expatriate assignments can cause considerable disruption (e.g. Fee, 2020; Fee and Michailova, 2020), especially if the assignments proceed in a short succession and are in key leadership roles. By focusing on retrospective accounts of HCEs from a single subsidiary which had been managed by a series of successive expatriate leaders, our study has generated a more nuanced understanding of the role that HCEs' past experiences play in subconsciously shaping their perceptions of expatriate leadership. Contrary to previous work which has linked past experiences and frequent interaction with expatriates with decreased stereotyping and more positive attitudes (e.g. Arman and Aycan, 2013; Selmer, 2001; Wang and Varma, 2018), our study has brought to the fore the relatively underexplored negative consequences of past experiences.

Building on insights from leadership transference studies (Ritter and Lord, 2007) and implicit leadership theories (e.g. Braun et al., 2017; Epitropaki et al., 2013; Junker and van Dick, 2014; Lord and Maher, 1993; Offermann and Coats, 2018; Offermann et al., 1994) our paper problematizes the limited attention paid to past experiences in affecting HCEs' perceptions of expatriates. As summarised in figure 1 below, our retrospective study of successive expatriate leadership has demonstrated that expatriate leaders are not only judged based on the qualities and behaviours they themselves exhibit, or the qualities or characteristics of the HCEs', as explored in the current literature (e.g. Stoermer et al., 2020; Varma et al., 2009; 2020; Zhang and Harzing, 2016). HCEs' evaluations of expatriate leaders are also affected by transferential processes, associated with HCEs' shared experiences with past expatriate leaders, their implicit leadership theories and the wider organisational, industry and cultural context. It is important to recognise that many of the qualities of individual expatriate leaders highlighted in previous studies on HCEs-expatriate relationships have also surfaced in our study. These included agreeableness, openness, perceived professionalism (Soko and Pillay, 2020), job knowledge and relational leadership skills (Templer, 2010) as well as ability 
to successfully operate in the local business context (Sonesh and DeNisi, 2016; Syed et al., 2014). However, our study demonstrates that these only partially explain HCEs' perceptions of successive expatriate leadership. As we argue, these can be better understood in contextually sensitive studies which consider the so far overlooked combined influences of transferential processes and implicit leadership theories.

Our study has shown that transferential processes associated with shared past experiences and HCEs' implicit leadership theories in a specific work context have jointly contributed to the formation of what we call HCEs' expatriate leadership schema (see Figure 1 for a visual representation of our findings).

[Insert Figure 1 about here]

This new concept of HCEs' expatriate leadership schema, as defined here, refers to cognitive structures of HCEs which they developed over the years, and which specify what they subjectively believe expatriate leadership to look like and what they expect from it. As our findings captured in figure 1 illustrate, shared past experiences with successive expatriate leaders influence HCEs' mental representations - cognitive structures here referred to as schema - of what expatriate leaders have in common, how they tend to behave and relate to HCEs when they assume general management of the local unit and, more broadly what expatriate leadership entails. The elements that are foregrounded in these mental representations are deeply contextually embedded. They direct HCEs' attention to the most salient aspects of expatriate leadership in a given context. They are also coloured by what they perceive leadership, in this case general management of a subsidiary operating in a given context, to look like and require. Again, these judgements are context sensitive and affected by HCEs' past experiences and transferential processes. In our case study, for example, the precarious financial position of the subsidiary exacerbated by its aging product portfolio and 
perceptions of the uniqueness and, relatedly, very specific requirements of the local market played a major role in both the evaluations of individual expatriate leaders and HCEs' implicit leadership theories.

In contrast to implicit leadership theories which refer to schemata describing a prototypical leader's traits and attributes (e.g. Braun et al., 2017; Epitropaki et al., 2013; Junker and van Dick, 2014; Offermann and Coats, 2018), expatriate leadership schema, as theorised in this paper, is a broader construct which goes beyond the focus on individual leaders. While it contains HCEs' implicit theories relating to expatriate leaders it also consists of two other elements: cognitive structures describing the perceived pattern of expatriate leadership and finally beliefs about its consequences. We will discuss each of these elements in more detail now.

In relation to the first component - expatriate leader theories - our findings suggest that these do not only contain traits and characteristics, as discussed in the leadership literature, but also comprise beliefs about prototypical behaviours of expatriate leaders, their motives and HCEs' expectation of treatment by expatriate leaders. These additional dimensions of HCEs' expatriate leader theories underscore the importance of the relational aspects of expatriateHCEs interactions. They resonate with Templer's (2010) findings which showed that relational leadership skills were seen as the most important contributor to expatriate success by their hostcountry national subordinates. The HCEs' shared expatriate leader theories found in our study were most pronounced among the longest serving staff and were not found among organisational newcomers.

The second component of expatriate leadership schema consists of beliefs about patterns of expatriate leadership. Expatriate leadership assignments in our case study were described by HCEs as displaying similar characteristics and unfolding in a familiar pattern. 
They were seen as being of a transitional nature, requiring a relatively long time to proficiency and being underpinned by change intensification in their second half. Contrary to the definitions adopted in the literature (e.g. Collings et al., 2007), assignments with an average length of two and a half years were seen as short. This perceived short succession of expatriate leaders who moved between assignments in different geographical locations contributed to perceptions of a transitional nature of these appointments.

The perceived long time to proficiency was largely linked to the challenges of work adjustments. Work adjustment to the General Manager's position was seen to require not only leadership competencies but also an understanding of the specificity of the local culture and market. This finding echoes earlier studies which reported HCEs' concerns about expatriate adjustment (e.g. Cheung, 2008; Syed et al., 2014) and the adverse consequences of asymmetrical understanding when expatriates overestimate their familiarity with the local context (Cheung, 2008). Our study has further revealed that potential benefits of expatriate proficiency were seen by HCEs to be compromised in the second half of their assignment by the need to secure the next placement. The concern with subsequent appointments was interpreted as resulting in change intensification focused on making a visible short-term impact necessary for expatriate career progression. HCEs' perceptions of expatriate assignment patterns have so far not been explored in the expatriate literature. We argue that this is an important oversight.

The final component of expatriate leadership schema, as depicted in figure 1, refers to the perceived consequences of successive expatriate leadership. These consequences were seen to affect individuals, expatriate-HCEs' relationships and the subsidiary as a whole. Negative consequences for individuals, such as increased stress, frustration and health problems, were most pronounced in discussions of the most recent expatriate General Manager, which can be explained by the recency of these experiences and their intensity. Consequences for expatriate- 
HCEs relationships and the subsidiary as a whole, by contrast, were associated with the aforementioned assignment pattern. In support of findings by Varma et al. (2009), the perceived short assignment length was found to impact HCEs' willingness and ability to build relationships with expatriates. Importantly, this was a concern not only for staff who had regular contact with expatriate leaders but also those in less senior positions. Finally, perceived negative consequences for the subsidiary were associated with their adverse effects on the formation and maintenance of a clear and stable vision and securing continuity.

It is important to recognise that a range of additional contextual factors, beyond the ones discussed above, are likely to have influenced the predominantly negative HCEs' expatriate leadership schema in our study. A significant factor was the nationally homogenous composition of the subsidiary. In homogenous contexts HCEs are more inclined to trust same nationality supervisors (Banai and Reisel, 1999). In such contexts a shared ethnic identity can gain in importance (compare Fan and Harzing, 2017), especially when expatriate leaders are seen to struggle with work and general adjustment. Furthermore, the expatriate leadership position is also consequential. Previous studies (e.g. Varma et al, 2011) have demonstrated that HCEs are more willing to support expatriates if they are their peers and subordinates. Expatriates in senior leadership positions can have a more far ranging and longer lasting effect on wider groups of staff and the hosting organisation as a whole. Expatriate leaders will be subject to increased scrutiny. Finally, in our case study, expatriate leaders were third country nationals who moved between assignments and had no substantial general management or host country context experience which has affected the perceptions of their suitability for their role, a crucial factor reported in the literature (e.g. Templer, 2010). These factors have reinforced the perception that the assignments were designed to mainly benefit the expatriates, a problem highlighted in earlier studies (e.g. Benenroth and Froese, 2020). The risk of perceptions of divergent goals increases when expatriate expertise and qualifications are perceived as 
insufficient to provide them with a clear advantage over local managers (Toh and DeNisi, 2005), or appear to be lacking in comparison.

\section{Implications for Theory}

Our findings have several important implications for theory. First, we conceptualised and empirically illustrated a so far unknown phenomenon - HCEs' expatriate leadership schema, which contains the poorly understood expatriate leader theories of HCEs. There is compelling evidence in the field of socio-cognitively oriented leadership studies of the implications of cognitive schema and transferential processes in shaping employees' perceptions of, attitudes towards and relationships with leaders (e.g. Epitropaki et al., 2013; Epitopaki and Martin, 2005; Offermann and Coats, 2018). Crucially, where cognitive schema of effective leadership differs between leaders and followers, this is likely to negatively impact leader-follower relationships (Riggs and Porter, 2017) and leadership effectiveness. The expatriate-HCEs relations literature would therefore be valuably extended by a systematic exploration of the emergence, content and role of the here proposed schema and its implications.

More generally, the study's findings highlight the importance of a shift from the dominant preoccupation with the qualities, characteristics and behaviours of individual expatriates, or a group of expatriates, studied in relative isolation to a more contextualised focus. This contextualised focus that we call for in this paper needs to consider the impact of transferential processes associated with HCEs' past experiences and former HCEs-expatriate relationships on HCEs' perceptions and the formation of new expatriate-HCEs relationships.

Second, our study suggests that HCEs' expatriate leadership schema, developed over time through prior experiences and socialisation processes (Lord and Maher, 1993; Oezbeck- 
Potthoff, 2014), are highly contextually situated. In our study, this schema was, for example, strongly influenced by implicit leadership theories associated with shared experiences with an influential past local executive. The expatriate leadership schema also contained other "contextually sensitive elements" (Offerman and Coats, 2018: 513), such as very particular expectations regarding the understanding of the local industry and market, which were linked to the perceived vulnerable position of the subsidiary. These insights demonstrate that the expatriate-HCEs relations literature would benefit from a fine-grained approach to context, beyond national values and HRM policies, and how it shapes these relations.

Third, current literature typically focuses on HCEs who have frequent contact with expatriates (e.g. Fee, 2020; Ljubica et al, 2019). Our study demonstrates that when studying successive expatriate assignments in senior leadership roles it is important to consider relationships beyond dyads as "leaders also have relationships with collectives" (Shamir, 2011: 311). HCEs engage in sensemaking by sharing stories, observations and experiences thus forming shared understandings which enhance the reach of the transferential effects of these shared experiences (Ritter and Lord, 2007). Moving to the social group level, we also note that implicit leadership theories have so far failed to consider shared leadership schema in detail (Schyns and Schilling, 2011). They have also not explicitly explored the impact of successive expatriate leader assignments. Based on our case study, we argue that shared negative experiences with successive expatriate leaders at a group level may influence individual expatriate schema. Since implicit leadership theories are likely to be seen by HCEs as depicting stable leader characteristics able to predict future behaviours (Lord and Dinh, 2014), exploring shared cognitive schema sheds light on "the frame in which followers begin engaging with leaders and which sets expectations for subsequent interactions" (Offermann and Coats, 2018: 514). 


\section{Practical implications}

The findings of our study have several practical implications for expatriates, subsidiary and corporate level HRM professionals and, more broadly, MNEs global staff policies. Incumbent expatriate leaders would benefit from an increased awareness of the subsidiary's history, HCEs' past experiences and the role these past experiences have in colouring HCEs' evaluations, expectations and reactions to them. This understanding could allow them to make conscious efforts to either highlight their uniqueness, in the case of strained past relationships between an expatriate and HCEs, or to emphasize similarity between themselves and a respected former leader. Recognising the importance that HCEs place on expatriates' contextual awareness, expatriate leaders should invest more in pre-assignment preparation not only in terms of enhancing their understanding of the local culture but also the local market, the position and history of the subsidiary and its past leaders.

Another crucial area of consideration is a sustained investment in the relational dimension of their role. Here, expatriate leaders need to be cognisant of how their decisionmaking styles can be interpreted by HCEs as signs of respect, or lack thereof, towards them and their expertise. They should also be very careful about expressing frustrations about the host country and host country nationals. Manifestations of their negative affect, even when unintentional, can contribute to HCEs' negative perceptions and attitudes. Furthermore, awareness of HCEs' possible negative implicit theories of successive assignment patterns can also help orient incumbent expatriate leaders to the challenges they may encounter and encourage them to interact with HCEs in ways which reaffirm their commitment to and investment in the subsidiary and relationships with staff. This may be done, among other strategies, by demonstrating the willingness to learn and use the local language. 
Subsidiary and corporate level HRM professionals can also benefit from an increased awareness of the existence and the role of expatriate leadership schema and transferential processes. Subsidiary level HRM professionals can use these insights to provide support for incumbent leaders by helping them understand the history of the subsidiary and staff's expectations. Corporate level HRM professionals responsible for delivering or commissioning pre-assignment training can ensure that the training raises expatriate leaders' awareness about the factors that are likely to affect HCEs' evaluations of them and how they are context and time sensitive.

Corporate level HRM professionals involved in the development and execution of global staffing policies can play an important role in counteracting HCEs' perceptions of a negative assignment pattern. In recognition of the potentially divergent perceptions of what constitutes a sufficient and mutually beneficial assignment length and its impact on the expatriate-local relations, decisions on assignment length need to take the local context into consideration. Organisations need to be aware of the limitations of successive expatriate leadership in nationally homogenous contexts and the potential this bears for transference and nurturing negative expatriate leadership schema.

Finally, our findings also support critical voices (e.g. De Nisi et al., 2006) by highlighting the risks associated with filling subsidiary executive roles with assignees on the move. Such staffing policy can cause suspicion among HCEs around the purpose of the assignment and undermine the HCEs' commitment to developing quality relationships with expatriate leaders. Attention needs to be directed towards expatriate succession instead of considering assignments in isolation. New appointments need to be made after careful consideration of HCEs' experiences with past expatriate assignments. 


\section{Limitations and Future Research}

Our study has contributed towards a more nuanced understanding of HCEs' negative perceptions of successive expatriate leadership by considering the role of their shared past experiences in the formation of HCEs' expatriate leadership schema. However, we recognise the limitations of this exploratory retrospective study which was carried out in a single organisation in one cultural context and from the subjective perspective of HCEs. We recognise that by focussing solely on HCEs' accounts, we are unable to corroborate whether their cognitive models of effective leadership coincide with or are different from those of the expatriate leaders. We are further unable to shed light on the strategic intent of the MNE and instructions that the expatriate GMs had received from HQ, which might have shed additional light on their attitudes towards HCEs and local processes. Future research could extend and refine our insights by using different methodologies and designs, such as comparative qualitative studies and studies adopting longitudinal designs. They could further explore implicit leadership theories of expatriate leaders and MNE strategies to assess the existence or absence of mutual fit of cognitive schema.

The role of transference and implicit leadership theories in affecting HCEs' expatriate leadership schema and expectations of expatriate skills, attributes and competences in different leadership roles warrants further attention. It would be valuable to investigate which conditions promote more positive expatriate leadership schema in the context of successive expatriate assignments and which factors mitigate the negative appraisal and possible transference effects. Comparative studies could provide rich insights into specific local contexts and shed more lights on "contextually sensitive elements" (Offerman and Coats, 2018: 513) of expatriate leadership schema. 


\section{References}

Andersen, N. (2019), Mapping the expatriate literature: a bibliometric review of the field from 1998 to 2017 and identification of current research fronts. The International Journal of Human Resource Management, 1-38: doi: 10.1080/09585192.2019.1661267.

Ariss, A., (2014), Voicing experiences and perceptions of local managers: Expatriation in the Arab Gulf', International Journal of Human Resource Management, 25(14): 1978-1994.

Arman, G., and Aycan, Z., (2013), Host country nationals' attitudes toward expatriates: development of a measure, International Journal of Human Resource Management, 24(15): 2927-2947.

Ballinger, G. A., and Schoorman, F. D. (2007), Individual reactions to leadership succession in workgroups. Academy of Management Review, 32(1), 118-136.

Banai, M., and Reisel, W. D., (1999), Would you trust your foreign manager? An empirical investigation'. International Journal of Human Resource Management, 10(3): 477-487.

Bebenroth, R., and Froese, F. J. (2020), Consequences of expatriate top manager replacement on foreign subsidiary performance. Journal of International Management, 26(2): 100730.

Berger, P. L. and Luckmann, T. (1966): The social construction of reality: a treatise in the sociology of knowledge, Garden City, NY: Doubleday.

Braun, V. and Clarke, V. (2012), Thematic analysis. In H. Cooper, P. M. Camic, D. L. Long, A. T. Panter, D. Rindskopf, \& K. J. Sher (Eds), APA handbook of research methods in psychology, Vol. 2: Research designs: Quantitative, qualitative, neuropsychological, and biological (pp. 57-71). Washington, DC: American Psychological Association.

Braun, S., Stegmann, S., Hernandez Bark, A.S., Junker, N.M. and van Dick, R. (2017), Think manager-think male, think follower-think female: Gender bias in implicit followership theories. Journal of Applied Social Psychology, 47(7): 377-388. 
Bruning, N.S., Bedenroth, R. and Pascha, W., (2011), Valuing Japan-based German expatriate and local manager's functions: do subsidiary age and managerial perspective matter?, International Journal of Human Resource Management, 22(4): 778-806.

Caligiuri, P. M., (2000), Selecting expatriates for personality characteristics: A moderating effect of personality on the relationship between host national contact and cross-cultural adjustment, Management International Review, 40(1): 61-80.

Cheung, L. L. W., (2008), Let the “other" speak for itself: Understanding Chinese employees from their own perspectives, Critical Perspectives on International Business, 4(2/3): 277306.

Collings, D. G., Scullion, H., and Morley, M. J., (2007), Changing patterns of global staffing in the multinational enterprise: challenges to the conventional expatriate assignment and emerging alternatives, Journal of World Business, 42(2): 198-213.

DeNisi, A. S., Toh, S. M., and Connelly, B., (2006), Building effective expatriate-host country national relationships: the effects of human resources practices, international strategy and mode of entry', In M. Morley, D.G. Collings and N. Heraty, (Eds.) International Human Resource Management and international assignments, Basingstoke: Palgrave Macmillan, pp. 1114-34.

Epitropaki, O., Sy, T., Martin, R., Tram-Quon, S. and Topakas, A. (2013), Implicit leadership and followership theories 'in the wild': Taking stock of information-processing approaches to leadership and followership in organizational settings. Leadership Quarterly, 24(6): $858-81$.

Fan, S. X., and Harzing, A. W. (2017), Host country employees' ethnic identity confirmation: Evidence from interactions with ethnically similar expatriates. Journal of World Business, 52(5), 640-652. 
Farah, B., Elias, R., De Clercy, C., and Rowe, G. (2020) Leadership succession in different types of organizations: What business and political successions may learn from each other. The Leadership Quarterly, 31(1): 101289.

Fee, A. (2020), How host-country nationals manage the demands of hosting expatriates. Journal of Global Mobility, 8(1): 25-54.

Fee, A., and Michailova, S. (2020), How host organizations prepare for and learn from expatriate assignments. Thunderbird International Business Review, 62(4), 329-342.

Grodzicki, J. and Varma, A., (2011), A comparative study of the impact of leader-member exchange in two samples: USA and Poland', Organizations and Markets in Emerging Economies, 2(1): 9-23.

Junker, N.M. and Van Dick, R. (2014), Implicit theories in organizational settings: A systematic review and research agenda of implicit leadership and followership theories. Leadership Quarterly, 25(6): 1154-73.

Kang, H., and Shen, J. (2018), Antecedents and consequences of host-country nationals' attitudes and behaviors toward expatriates: What we do and do not know. Human Resource Management Review, 28(2), 164-175.

Kets de Vries, M. and Balazs. K., (2011), The Shadow Side of Leadership, In A. Bryman, D. Collinson, K. Grint, B. Jackson and M. Uhl-Bien, (Eds.) The Sage Handbook of Leadership, London: Sage Publications, pp. 380-392.

Ljubica, J., Shaffer, M., Tin, S., and McKouen, K. (2019), A model of the dark side of expatriate-host country national relationships. Journal of Global Mobility, 7(2): 137-156.

Lord, R. G., and Dinh, J. E. (2014). What have we learned that is critical in understanding leadership perceptions and leader-performance relations?. Industrial and Organizational Psychology, 7(2), 158-177. 
Lord, R. G., and Emrich, C. G. (2000). Thinking outside the box by looking inside the box: Extending the cognitive revolution in leadership research. The Leadership Quarterly, 11(4), 551-579.

Lord, R.G. and Maher, K.J. (1993), Leadership and Information Processing. London: Routledge.

Mahajan, A., (2011), Host country national's reactions to expatriate pay policies: making a case for a cultural alignment pay model, International Journal of Human Resource Management, 22(1): 121-137.

Mahajan, A., and De Silva, S. R., (2012), Unmet role expectations of expatriates, host-country national support, and expatriate adjustment, International Journal of Cross-Cultural Management, 12(3): 349-360.

Mantere, S., and Ketokivi, M. (2013). Reasoning in organization science. Academy of Management Review, 38(1), 70-89.

Offermann, L. R., and Coats, M. R. (2018). Implicit theories of leadership: Stability and change over two decades. The Leadership Quarterly, 29(4), 513-522.

Offermann, L.R., Kennedy, J.K. and Wirtz, P.W. (1994), Implicit leadership theories: Content, structure and generalizability. Leadership Quarterly, 5: 43-58.

Peltokorpi, V. (2020), Host Country National Employees' Prosocial Behavior toward Expatriates in Foreign Subsidiaries: A Common Ingroup Identity Model Perspective. International Business Review, 29(2), 101642.

Peltokorpi, V., and Froese, F., (2014), Expatriate personality and cultural fit: The moderating role of host country context on job satisfaction, International Business Review, 23(1): 293302. 
Peltokorpi, V., and Pudelko, M. (2021), When more is not better: A curvilinear relationship between foreign language proficiency and social categorization. Journal of International Business Studies, 52: 78-104.

Pettigrew, A. M. (1990), Longitudinal field research on change: Theory and practice. Organization Science, 1: 267-292.

Piekkari R. and Welch, C. (2018) The case study in management research: Beyond the positivist legacy of Eisenhardt and Yin? In: C. Cassell, A. Cunliffe, G. Grandy (Eds.), Sage Handbook of Qualitative Business and Management Research Methods, pp. 345-358, Sage: Thousand Oaks.

Plakoyiannaki, E., and Budhwar, P. (2021). From convention to alternatives: rethinking qualitative research in management scholarship, British Journal of Management, 32: DOI:

\section{$10.1111 / 1467-8551.12464$}

Przytuła, S., Rozkwitalska, M., Chmielecki, M., Sułkowski, Ł., and Basinska, B. A., (2015), Cross-Cultural Interactions between Expatriates and Local Managers in the Light of Positive Organizational Behaviour, Social Sciences, 86(4), 14-24.

Riggs, B.S. and Porter, C.O.L.H. (2017), Are there advantages to seeing leadership the same? A test of the mediating effects of LMX on the relationship between ILT congruence and employees' development. Leadership Quarterly, 28(2): 285-299.

Ritter, B. A., and Lord, R. G., (2007), The impact of previous leaders on the evaluation of new leaders: an alternative to prototype matching, Journal of Applied Psychology, 92(6): 1683-

Rosch, E. (1978), Principles of categorization. In E. Rosch and B. Lloyd (eds) Cognition and Categorization. Hillsdale, NJ: Lawrence Erlbaum, 27-48.

Sætre, A. S., and Van de Ven, A. H. (2021). Generating Theory by Abduction. Academy of Management Review, amr.2019.0233. https://doi.org/10.5465/amr.2019.0233 
Schyns, B. and Schilling, J. (2011), Implicit leadership theories: Think leader, think effective? Journal of Management Inquiry, 20(2): 141-50.

Shondrick, S. J., Dinh, J. E., and Lord, R. G. (2010). Developments in implicit leadership theory and cognitive science: Applications to improving measurement and understanding alternatives to hierarchical leadership. The Leadership Quarterly, 21(6), 959-978.

Selmer, J., (1996), Expatriate or local bosses? HCN subordinates' preferences in leadership behaviour, International Journal of Human Resource Management, 7(1): 165-178.

Selmer, J., (1997), Differences in leadership behaviour between expatriate and local bosses as perceived by their host country national subordinates, Leadership and Organization Development Journal, 18(1), 13-22.

Selmer, J., (2001), Antecedents of expatriate/local relationships: pre-knowledge vs. socialization tactics, International Journal of Human Resource Management, 12(6): 916925.

Selmer, J., and Lauring, J., (2013), Dispositional affectivity and work outcomes of expatriates, International Business Review, 22(3): 568-577.

Shamir, B. (2011), Leadership takes time: Some implications of (not) taking time seriously in leadership research. The Leadership Quarterly, 22(2), 307-315.

Shen, J., Kang, H., and Dowling, P. J. (2018), Conditional altruism: Effects of HRM practices on the willingness of host-country nationals to help expatriates. Human Resource Management, 57(1), 355-364.

Sokro, E., and Pillay, S. (2020), Host Country Nationals' Attitudes, Social Support and Willingness to Work with Expatriates. Global Business Review, 21(5), 1184-1199.

Sonesh, S. C., and DeNisi, A. S. (2016), The categorization of expatriates and the support offered by host country nationals. Journal of Global Mobility, 4(1): 18-43. 
Song, L. J., Zhong, M., Shi, J., Wang, Y., and Meng, H., (2015), The Impact of Previous LMX Relationship on Current LMX Relationship: A Social Cognitive Model of Transference, Frontiers of Business Research in China, 9(1): 44-63.

Stake, R. E. (2005). Qualitative case studies. In N. K. Denzin \& Y. S. Lincoln (eds.), The Sage handbook of qualitative research $\left(3^{\text {rd }}\right.$ ed), pp. 236-47. Thousand Oaks, CA: Sage Publications

Stock, R.M. and Oezbeck-Potthoff, G. (2014), Implicit leadership in an intercultural context: Theory extension and empirical investigation. International Journal of Human Resource Management, 25(12): 1651-68.

Stoermer, S., Davies, S., and Froese, F. J. (2020), The influence of expatriate cultural intelligence on organizational embeddedness and knowledge sharing: The moderating effects of host country context. Journal of International Business Studies, https://doi.org/10.1057/s41267-020-00349-3.

Strauss, A., and Corbin, J. (1998). Basics of qualitative research: Techniques and procedures for developing grounded theory (2nd ed.). Thousand Oaks, CA: Sage.

Syed, J., Hazboun, N. G., and Murray, P. A., (2014), What locals want: Jordanian employees' views on expatriate managers, International Journal of Human Resource Management, 25(2): 212-233.

Templer, K. J., (2010), Personal attributes of expatriate managers, subordinate ethnocentrism, and expatriate success: A host-country perspective, International Journal of Human Resource Management, 21(10): 1754-1768.

Thornberg, R and Charmaz, K (2014) 'Grounded Theory and Theoretical Coding', in Flick, U (ed), The Sage Handbook of Qualitative Data Analysis, pp. 153-169. London: Sage.

Toh, S. M., and DeNisi, A. S., (2005), A local perspective to expatriate success', The Academy of Management Executive, 19(1): 132-146. 
Toh, S. M., and Srinivas, E. S. (2012), Perceptions of task cohesiveness and organizational support increase trust and information sharing between host country nationals and expatriate coworkers in Oman. Journal of World Business, 47(4), 696-705.

Van Bakel, M. (2019), It takes two to tango: a review of the empirical research on expatriatelocal interactions. The International Journal of Human Resource Management, 30(21), 2993-3025.

van Bakel, M., van Oudenhoven, J. P., and Gerritsen, M. (2015), Developing a high-quality intercultural relationship: expatriates and their local host. Journal of Global Mobility, 3(1): $25-45$.

Varma, A., Aycan, Z., Budhwar, P., Pichler, S., Uygur, U., and Paluch, R. (2016a), Host country nationals' support to expatriates: an investigation in Turkey. European Journal of International Management, 10(6), 605-623.

Varma, A., Budhwar, P., Katou, A., and Matthew, J. (2016b), Interpersonal affect and host country national support of expatriates: An investigation in China. Journal of Global Mobility, 4(4): 476-495.

Varma, A., Budhwar, P., and Pichler, S., (2011a), Chinese host country nationals' willingness to help expatriates: The role of social categorization, Thunderbird International Business Review, 53(3): 353-364.

Varma, A., Pichler, S., and Budhwar, P., (2011b), The relationship between expatriate job level and host country national categorization: an investigation in the UK, International Journal of Human Resource Management, 22(1): 103-120.

Varma, A., Pichler, S., Budhwar, P., and Biswas, S., (2009), Chinese Host Country Nationals' Willingness to Support Expatriates: The Role of Collectivism, Interpersonal Affect and Guanxi', International Journal of Cross-Cultural Management, 9(2): 199-216. 
Varma, A., Pichler, S., Budhwar, P., and Kupferer, S., (2012), Expatriate-local interactions: an investigation in China, Journal of Managerial Psychology, 27(7): 753-768.

Varma, A., Yoon, Y. J., and Froese, F. J. (2020), Expatriate demographic characteristics and host country national support: an empirical investigation in Central/South America. Cross Cultural \& Strategic Management. https://doi.org/10.1108/CCSM-02-2020-0036

Wang, D., Feng, T., Freeman, S., Fan, D., and Zhu, C. J., (2014), Unpacking the "skill-crosscultural competence" mechanisms: Empirical evidence from Chinese expatriate managers, International Business Review, 23(3): 530-541.

Wang, C. H., and Varma, A. (2018). A process model of how interpersonal interaction leads to effectiveness of the expatriate-host country national relationship: An intergroup contact perspective. Cross Cultural and Strategic Management, 25(4): 670-689.

Waxin, M. F., Brewster, C., and Ashill, N. (2019). Expatriate time to proficiency: individual antecedents and the moderating effect of home country. Journal of Global Mobility, 7(3): 300-318.

Yamao, S., Yoshikawa, T., Choi, D., and Toh, S. M. (2020), When do host country nationals help expatriates? The roles of identification with the multinational enterprise and career development support by the subsidiary. Journal of International Management, 26(3), 100778.

Zhang, L. E., and Harzing, A. W. (2016), From dilemmatic struggle to legitimized indifference: Expatriates' host country language learning and its impact on the expatriate-HCE relationship. Journal of World Business, 51(5), 774-786. 


\begin{tabular}{|c|c|c|c|c|}
\hline $\begin{array}{l}\text { Participant } \\
\text { (pseudonym) }\end{array}$ & Sex & Position & $\begin{array}{l}\text { Length of } \\
\text { service } \\
\text { (years) }\end{array}$ & $\begin{array}{l}\text { No. of observed } \\
\text { expatriate EAs }\end{array}$ \\
\hline 1 Anna & $\mathrm{F}$ & Director & 12 & 4 \\
\hline 2 Monika & $\mathrm{F}$ & Middle manager & 10 & 4 \\
\hline 3 Norbert & M & Specialist & 9 & 4 \\
\hline 4 Tomasz & $\mathrm{M}$ & Specialist & 9 & 4 \\
\hline 5 Kacper & M & Rep & 9 & 4 \\
\hline 6 Szymon & M & Director & 9 & 4 \\
\hline 7 Danuta & M & Specialist & 9 & 4 \\
\hline 8 Irek & M & Middle manager & 8 & 4 \\
\hline 9 Darek & M & Specialist & 8 & 4 \\
\hline 10 Lucyna & $\mathrm{F}$ & Administrator & 7 & 3 \\
\hline 11 Jarek & M & Specialist & 7 & 3 \\
\hline 12 Paula & $\mathrm{F}$ & Specialist & 6 & 3 \\
\hline 13 Tatiana & $\mathrm{F}$ & Assistant & 6 & 3 \\
\hline 14 Jan & M & Administrator & 6 & 3 \\
\hline 15 Edward & M & Middle manager & 6 & 3 \\
\hline 16 Kamil & M & Rep & 6 & 3 \\
\hline 17 Adam & M & Rep & 6 & 3 \\
\hline 18 Jacek & M & Middle manager & 6 & 3 \\
\hline 19 Włodek & M & Administrator & 6 & 3 \\
\hline 20 Olek & M & Specialist & 5 & 3 \\
\hline 21 Małgorzata & $\mathrm{F}$ & Specialist & 5 & 3 \\
\hline 22 Ewa & $\mathrm{F}$ & Middle manager & 5 & 3 \\
\hline 23 Magdalena & $\mathrm{F}$ & Administrator & 4 & 2 \\
\hline 24 Bogusia & $\mathrm{F}$ & Middle manager & 4 & 2 \\
\hline 25 Grzegorz & M & Middle manager & 4 & 2 \\
\hline 26 Mirek & M & Middle manager & 4 & 2 \\
\hline 27 Sara & $\mathrm{F}$ & Specialist & 3 & 2 \\
\hline 28 Adam & M & Director & 3 & 2 \\
\hline 29 Alicja & $\mathrm{F}$ & Administrator & 3 & 2 \\
\hline 30 Roman & M & Administrator & 3 & 2 \\
\hline 31 Oliwia & $\mathrm{F}$ & Administrator & 3 & 1 \\
\hline 32 Renata & $\mathrm{F}$ & Assistant & 3 & 1 \\
\hline 33 Ilona & $\mathrm{F}$ & Rep & 3 & 1 \\
\hline 34 Patrycja & $\mathrm{F}$ & Director & 3 & 1 \\
\hline 35 Teresa & $\mathrm{F}$ & Director & 3 & 1 \\
\hline 36 Borys & M & Rep & 2 & 1 \\
\hline 37 Michał & M & Specialist & 2 & 1 \\
\hline 38 Ela & $\mathrm{F}$ & Specialist & 2 & 1 \\
\hline 39 Norbert & M & Director & 2 & 1 \\
\hline 40 Patryk & M & Director & 2 & 1 \\
\hline
\end{tabular}

Table 1 Sample composition 
